\title{
Hygiene in Commercial Dishwashing - A Review about the State of Knowledge in Research, Standardization, Regulation and Market Information
}

\begin{abstract}
The current state of knowledge about hygiene (efficacy testing) in commercial dishwashers will be collated in this review. Therefore, studies about hygiene in commercial dishwashing are summarised and existing standards, guidelines and the legislative basis described. Finally, examples of information available from the market, for example, detergents are presented. The use of bioindicators contaminated with bovine albumin, mucin, corn starch and Enterococcus faecium is widely established in studies, which was the basis for the introduction of standards. Standards prescribe minimum temperatures for cleaning and rinsing, and most of them provide microbiological testing methods. A worldwide standardized test method for hygiene in commercial dishwashers would guarantee the comparability of country-specific standards but procedures currently available would need great efforts to be unified. A definition of a specified hygiene target level on cleaned dish items would also be meaningful because a harmless level of microorganisms can be achieved with it regardless of the initial microbial count or the process used.
\end{abstract}

Keywords: hygienic efficacy, commercial dishwashing, warewasher, microbial reduction, Enterococcus faecium

\section{Hygiene im gewerblichen Geschirrspülen - Ein Überblick über den Stand des Wissens in Forschung, Normung, Regu- lierung und Marktinformation.}

Zusammenfassung: Der aktuelle Wissensstand zur Hygiene (Effizienzprüfung) im gewerblichen Geschirrspülen soll in diesem Übersichtsbeitrag dargestellt werden. Dazu werden Studien zur Hygiene im gewerblichen Geschirrspülen zusammengefasst, bestehende Normen und Richtlinien sowie die gesetzlichen Grundlagen beschrieben. Abschließend werden Beispiele für verfügbare Marktinformationen von z. B. Reiniger vorgestellt. Die Verwendung von Bioindikatoren, die mit Rinderalbumin, Mucin, Maisstärke sowie Enterococcus faecium kontaminiert sind, ist durch Studien weithin etabliert und bildete die Grundlage für einige Normen. Die Normen schreiben Mindesttemperaturen für die Reinigung und Klarspülung vor sowie meist auch mikrobiologische Testmethoden. Ein weltweit standardisiertes Testverfahren zur Überprüfung der Hygiene bei gewerblichen Geschirrspülmaschinen würde die Vergleichbarkeit innerhalb

University of Bonn, Institute of Agricultural Engineering/Household Technology, Bonn, Germany

Bielefeld, Germany der länderspezifischen Normen gewährleisten, jedoch müssten die derzeit verfügbaren Verfahren mit hohem Aufwand vereinheitlicht werden. Sinnvoll wäre auch die Definition eines festgelegten Hygienezielniveaus auf gereinigtem Spülgut, da damit unabhängig von der Ausgangskeimzahl und dem verwendeten Verfahren ein unbedenkliches Niveau an Mikroorganismen erreicht werden kann.

Stichwörter: Hygieneeffizienz, gewerbliches Geschirrspülen, Spülmaschine, Keimreduktion, Enterococcus faecium

\section{Introduction}

Hygiene is important in all areas of daily life, particularly in commercial dishwashing since a wide range of consumers is affected. Every gastronomic establishment and kitchen for community catering, such as restaurants, canteens, nursing homes, kindergartens and hospitals, or caterers use commercial dishwashers [1]. Each consumer is entitled to have hygienically clean dishes and cutlery [2]. In this context, dishwashing is one important means to prevent the spread of potential pathogenic microorganisms that can be present on dishes and cutlery and to break the chain of infection [3]. This is especially important considering the changing general conditions, such as the increasing number of vulnerable people (YOPI = young, old, pregnant, immunocompromised), and the appearance of more antibiotic resistances or new infections and strains [4], such as the currently rampant coronavirus (SARS-CoV-2) that has caused a pandemic starting in Wuhan (China) in 2019 [5].

The principles of hygiene procedures are common to all; however, approaches currently used in different settings are inconsistent. Therefore, Bloomfield et al. [6] proposed an unified framework for developing, standardizing and comparing the efficacy of hygiene procedures which can be used in any type of setting and applied to any type of surface or item. It will ensure a consistent hygiene target level regardless of the procedure used. This approach proposes a hierarchy for testing hygiene procedures by the means of four subsequent stages (Table 1).

The first two stages will ensure the antimicrobial efficacy of the products in suspension and surface tests to guarantee the proof of principle. Stage 3 demonstrates that the hygiene procedure (combining the product and the application process of the product) can achieve a specified hygiene target 


\begin{tabular}{|c|c|c|}
\hline Stage 1 & Establish antimicrobial efficacy of products in suspension tests & \multirow{2}{*}{ Proof of principle } \\
\hline Stage 2 & Establish antimicrobial efficacy of products in surface tests & \\
\hline Stage 3 & $\begin{array}{l}\text { Demonstrate hygiene procedure (product + process) delivers specified safety target levels on } \\
\text { surfaces, under conditions of use (fitness of purpose) }\end{array}$ & Fitness of purpose \\
\hline Stage 4 & $\begin{array}{l}\text { Demonstrate reduced infection rates through clinical intervention studies, or quantitative mi- } \\
\text { crobiological risk assessments in non-healthcare settings (clinical impact) }\end{array}$ & Clinical impact \\
\hline
\end{tabular}

Table 1 Hierarchy for hygiene procedure testing according to Bloomfield et al. [6].

level under practical conditions of use. Thereby, the fitness of purpose will be ensured. Stage 4 is the criterion standard, where the clinical impact of the antimicrobial efficacy will be proven as reduced infection rates in intervention studies. Moreover, a consistent terminology for describing the hygiene efficacy (i.e. hygienically clean) will help to standardize the communication [6].

This review covers various types of commercial dishwashers; an overview is presented in Table 2. The different types of commercial dishwashers are generally used according to the cleaning capacity needs of the customers. Undercounter water-change and undercounter one-tank dishwashers are manually loaded programme automats with water-change operation or one-tank and glasswashers. Hood-type dishwashers apply to customers that have a capacity need between that of typical front-load dishwashers and conveyor-type dishwashers. When larger or more irregular dishwashing needs (e.g. large pots or pans) are desired, the utensil or pot dishwasher is the best solution. Finally, onetank or multi-tank conveyor-type dishwashers are used in large restaurants or institutional cafeteria with a high-capacity cleaning demand [7].

\section{Scientific basis for the development of hygiene requirements in commercial dishwashing}

A test for checking the hygienic efficacy of commercial dishwashers has been demanded for many years. The German working group "Food Hygiene," within the DIN standardization committee for foodstuffs and agricultural products NAL, was founded in 1989 to establish general regulations for the hygienic use of dishwashers and develop test methods for the microbiological control of these systems. Sonntag et al. [10] tested 70 multi-tank conveyor-type dishwashers in a ring trial to collect basic data. Microbiological testing was performed by contact sampling of the surface of dishes and by sampling of the cleaning solution in the last tank before rinsing. The surface checks of the dishes showed that the number of highly contaminated items is significantly higher when using low temperatures and a low chlorine amount in the detergent. Gram-negative bacteria did not survive a temperature of $60^{\circ} \mathrm{C}$ for more than $2 \mathrm{~min}$ in an alkaline cleaning solution. Moreover, no E. coli or coliforms were found. This test method demonstrates clearly the impact of temperature and chlorine on the microbial inactivation: A water temperature $>60^{\circ} \mathrm{C}$ and a chlorine content $>10 \mathrm{ppm}$ achieved the highest reduction with an average microbial count of 10 colony-forming units (cfu) per mL. The results confirmed that contact plates could only be used as a rough estimate, but the investigation of the cleaning solution gives representative results. Therefore, the combination of surface plating of cleaned dishes and microbiological control of the cleaning solution allows a valid evaluation of the efficacy of the dishwashing process. It was recommended to achieve a minimum water temperature of $60^{\circ} \mathrm{C}$ and a chlorine concentration about $10 \mathrm{ppm}$ for an acceptable microbiological-hygienic standard of multi-tank conveyortype dishwashers [10].

Based on these results, Höller et al. [11] aimed to validate the findings with specific re-examinations in multi-tank conveyor-type dishwashers. It was confirmed that contact plates could only serve as a rough estimate of the hygienic condition since even significant influences of temperature, time and chlorine concentration were not reflected. However, the total bacterial counts measured in the last cleaning solution prior to the final rinsing zone reflect clearly the impact of parameters, as to be expected, from the first ring trial [11]. Long contact times may enhance the microbial reduction on dishes at medium and high temperatures since an elongation of time in the cleaning solution will improve the decomposition and mechanical removal of food particles and, thereby, microorganisms. Nevertheless, long contact times

\begin{tabular}{|c|c|c|c|c|c|c|}
\hline $\begin{array}{c}\text { Dishwasher } \\
\text { type }\end{array}$ & $\begin{array}{c}\text { Undercounter } \\
\text { water-change } \\
\text { dishwasher }\end{array}$ & $\begin{array}{c}\text { Undercounter } \\
\text { one-tank dish- } \\
\text { washer }\end{array}$ & $\begin{array}{c}\text { Hood-type } \\
\text { dishwasher }\end{array}$ & $\begin{array}{c}\text { Utensil or pot } \\
\text { dishwasher }\end{array}$ & $\begin{array}{c}\text { One-tank con- } \\
\text { veyor-type } \\
\text { dishwasher }\end{array}$ & $\begin{array}{c}\text { Multi-tank con- } \\
\text { veyor-type } \\
\text { dishwasher }\end{array}$ \\
\hline Water supply & $\begin{array}{c}\text { water-change } \\
\text { operation }\end{array}$ & $\begin{array}{c}\text { tank system/ } \\
\text { one-tank }\end{array}$ & $\begin{array}{c}\text { tank system/ } \\
\text { one-tank }\end{array}$ & $\begin{array}{c}\text { tank system/ } \\
\text { one-tank }\end{array}$ & $\begin{array}{c}\text { tank system/ } \\
\text { one-tank }\end{array}$ & $\begin{array}{c}\text { tank system/ } \\
\text { multi-tank }\end{array}$ \\
\hline $\begin{array}{c}\text { Type of } \\
\text { washware to } \\
\text { be cleaned }\end{array}$ & $\begin{array}{c}\text { dishes, glasses, } \\
\text { cutlery, pots and } \\
\text { pans, utensils }\end{array}$ & $\begin{array}{c}\text { mainly plates, } \\
\text { glasses, cups, } \\
\text { cutlery }\end{array}$ & $\begin{array}{c}\text { mainly plates, } \\
\text { glasses, cups, } \\
\text { cutlery }\end{array}$ & $\begin{array}{c}\text { black cookware, } \\
\text { large utensils }\end{array}$ & $\begin{array}{c}\text { mainly plates, } \\
\text { glasses, cups, } \\
\text { cutlery, trays }\end{array}$ & $\begin{array}{c}\text { mainly plates, } \\
\text { glasses, cups, } \\
\text { cutlery, trays }\end{array}$ \\
\hline $\begin{array}{c}\text { Capacity } \\
\text { needs/Area of } \\
\text { application }\end{array}$ & \multicolumn{2}{|c|}{ low } & $\begin{array}{c}\text { medium/ } \\
\text { commercial } \\
\text { restaurants }\end{array}$ & $\begin{array}{c}\text { medium/ } \\
\text { larger or } \\
\text { irregular needs }\end{array}$ & $\begin{array}{c}\text { high/large restaurants or institutional } \\
\text { cafeterias }\end{array}$ \\
\hline
\end{tabular}

Table 2 Overview of different types of commercial dishwashers [7]. 
cannot fully replace a chemical inactivation of microorganisms, especially at lower temperatures. The recommended value of $100 \mathrm{cfu} / \mathrm{mL}$ in cleaning solutions can be postulated based on the results of both ring trials. Suitable germ carriers (i. e. bioindicators) that mirror the influence of all major parameters influencing the microbial reduction could be used additionally for hygienic acceptance testing or specific investigations [11].

Therefore, a third part of the ring trial was conducted with bioindicators to assess the hygienic efficacy in different parts of the multi-tank conveyor-type dishwashers. The objective of Krüger et al. [12] was to establish suitable bioindicators with a corresponding test contamination and definition of the worst-case position in the dishwasher. E. faecium ATCC 6057 was used as a test strain since it is particularly resistant to temperatures up to $70^{\circ} \mathrm{C}$ and chemicals. The microbial reduction caused by the dishwashing process was highly correlated to the roughness of the bioindicators. Moreover, the drying time had a crucial influence on the mechanical removal of microorganisms; the longer the soiling could dry on the items, the more difficult it was to remove. The most satisfactory bioindicators are stainless steel items ( 80 grade) contaminated with BAMS $(0.6 \%$ beef albumin, $1 \%$ mucin, $3 \%$ maize starch) and $>10^{7} \mathrm{cfu}$ E. faecium ATCC 6057 , dried up at $20^{\circ} \mathrm{C}$ to $22^{\circ} \mathrm{C}$ and $50 \%$ to $75 \%$ relative humidity. These bioindicators are able to achieve a $5-\log _{10}$ reduction and can show hygiene deficiencies in the dishwashing process. Spraying shadows resulted in a reduced removal of soil and microorganisms, therefore, tests in the cutlery rack (considered as worst-case) are recommended [12].

The data of the ring trials [10-12] were used to publish the draft DIN 10510 "Food Hygiene; Commercial Dishwashers with Multiple Tank Conveyor Belt Dishwashing Machines; Hygienic Requirements, Testing" in 1995. In this draft, bioindicators, serving as a model for cutlery for process validation, are contaminated with BAMS and E. faecium ATCC 6057, as proposed by Krüger et al. [12]. Temperature and contact time were identified as crucial parameters influencing the microbial inactivation in a dishwashing cycle. As an orientation, contact samples resulting in $>5 \mathrm{cfu} / 10 \mathrm{~cm}^{2}$ indicate a lack of hygiene. The requirement arising from tests with bioindicators is that at least eight bioindicators need to reach a $5-\log _{10}$ reduction. An approximate value of $200 \mathrm{cfu} / \mathrm{mL}$ and an alarm value of $500 \mathrm{cfu} / \mathrm{mL}$ were set as a total microbial count in the cleaning solution of multi-tank conveyor-type dishwashers. High numbers of yeasts, fungi and spore-forming microorganisms, micrococci and staphylococci could be found below $60^{\circ} \mathrm{C}$. A hygienically clean result can be achieved with good pre-cleaning, temperatures $>60^{\circ} \mathrm{C}$ for $2 \mathrm{~min}$ in one of the cleaning tanks (or $10 \mathrm{ppm}$ chlorine in the detergent at temperatures $<60^{\circ} \mathrm{C}$ ), sufficient fresh water renewal and an effective use of a detergent [13].

Next to dishes and cutlery, drinking glasses are subject to transmission of microorganisms from mouth to mouth. Therefore, Krüger and Zschaler [2] aimed to build a scientific basis for the standard development of glass washing machines (DIN 10511). Methods for microbiological testing were adopted for the most part from DIN 10510 for multi-tank conveyor-type dishwashers. However, in contrast to the use of bioindicators with BAMS and E. faecium, special methods were developed for testing the microbial reduction on glasses in glass washing machines with one tank and freshwater rinse. The standardized beaker glass and wine tasting glass were used as test glasses. Drinking cacao, beer wort suspension, UHT milk and reconstituted skimmed milk were also tested in addition to BAMS as test soiling media. The milk appeared to be suitable since a high backlog quantity in the glasses could be realised, which reflects the realistic condition of drinking glasses. A cleaning temperature of $50^{\circ} \mathrm{C}$ in the presence of detergent without active chlorine resulted in a significantly lower reduction compared to higher temperatures or the use of detergent with active chlorine. Concerning practical conditions, a temperature of $55^{\circ} \mathrm{C}$ in the short programme with only $1.5 \mathrm{~g} / \mathrm{L}$ detergent achieved a $5-\log _{10}$ reduction even at $5 \mathrm{~h}$ drying time in the beaker glass. The results of the wine tasting glass showed an even higher reduction at $2 \mathrm{~h}$ drying. The form of the glasses is a difficulty since it has a significant influence on the microbial inactivation and mechanical removal, for example, narrow-necked glasses show low reductions. The milk soiling was defined as worst-case soiling. However, the BAMS soiling showed a high persistence due to the starch component and could only be reduced sufficiently at $65^{\circ} \mathrm{C}$. High-risk areas, such as hospitals, which might be confronted with a starchy soiling (i.e. oat meal residues) can make use of higher temperatures, longer contact times and a detergent containing active chlorine to get hygienically clean glasses. It is generally recommended to clean the drinking glasses in the dishwasher. [2]

Kerschgens et al. [15] aimed to check whether a nonpathogenic germ with similar sensitivity to temperature and time could replace the potential pathogenic test strain E. faecium of DIN SPEC 10534, the pre-standard summarising standards for testing the hygienic efficacy of different types of commercial tank dishwashers. Moreover, it should be evaluated whether the hygienic efficacy of water-change dishwashers could also be tested according to DIN SPEC 10534 [25]. Experiments in an undercounter one-tank dishwasher aimed to evaluate the influence of different combinations of temperatures $\left(45^{\circ} \mathrm{C}, 55^{\circ} \mathrm{C}\right.$ and $\left.65^{\circ} \mathrm{C}\right)$ and holding times $(60 \mathrm{~s}, 120 \mathrm{~s}$ and $180 \mathrm{~s})$ in the cleaning process on the microbial reduction. Higher temperatures and longer holding times led to a significantly higher reduction. An increase of temperature of $10 \mathrm{~K}$ had a significant effect on the reduction when testing the same holding time. Tests in a waterchange dishwasher were performed using the short programme with different combinations of holding times $(60 \mathrm{~s}$, $90 \mathrm{~s}$ and $120 \mathrm{~s}$ ), and cleaning and rinsing temperatures $\left(30^{\circ} \mathrm{C}, 45^{\circ} \mathrm{C}, 55^{\circ} \mathrm{C}\right.$ and $\left.65^{\circ} \mathrm{C}\right)$. The hygienic efficacy generally changed if the temperature and holding time of the cleaning and rinsing processes were varied. An increase of temperature and holding time led to a higher reduction and an increase of cleaning temperature has a greater antimicrobial effect compared to the same rinsing temperature. Test runs with a cleaning temperature of $55^{\circ} \mathrm{C}$ and $65^{\circ} \mathrm{C}$ showed an appropriate hygiene efficacy. Furthermore, a rinsing temperature of $55^{\circ} \mathrm{C}$ for $120 \mathrm{~s}$ and $65^{\circ} \mathrm{C}$ for $60 \mathrm{~s}$ achieved a hygienically clean result. The initial investigation of this study identified $M$. luteus as an appropriate test strain to replace E. faecium, especially in studies with undercounter one-tank dishwashers [15]. 
Further studies $[1,16]$ were carried out with $M$. luteus because the use of Biosafety level 1 microorganisms is especially advantageous since every microbiological laboratory and laboratory for dishwashing efficacy testing can carry out tests. The aim of Klapper et al. [1] was to verify the suitability of selected $M$. luteus strains as test strains for hygiene tests in commercial dishwashers by checking its heat resistance in comparison to E. faecium and conducting tests with bioindicators in a water-change dishwasher. The heat resistance tests showed that M. luteus DSM 28269 has a lower thermostability than $M$. luteus DSM 1790. The strain DSM 1790 showed similar results compared to the established E. faecium. Growth was verifiable at temperatures between $45^{\circ} \mathrm{C}$ and $70^{\circ} \mathrm{C}$ in both cases. The hygiene tests in the dishwasher showed that a clear reduction has been achieved in the short and the intensive programme for all strains tested. Klapper et al. [1] concluded that M. luteus DSM 1790 is an optimal alternative for hygiene testing since it has a heat resistance correlating with the one of E. faecium. However, the results are only valid for investigations in the lower basket of a water-change dishwasher since possible effects that might occur in the upper basket are not considered. Thus, it is necessary to develop a general method for testing water-change and tank dishwashers [1].

Zinn et al. [16] performed a study in 2018 to develop a test method for commercial dishwashers operating on the fresh water principle. The test soiling BAMS of DIN SPEC 10534 do not appear to be recommendable for commercial dishwashers operating on the water-change system due to their inappropriate adhesion to stainless steel bioindicators. Therefore, oat flakes, as a new test soiling medium, in combination with $M$. luteus DSM 1790 were applied on test plates using a template and tested in a water-change dishwasher. Utilising this test method, Zinn et al. [16] have achieved a differentiation in the microbial reduction of the dishwashing process. Detergent containing bleach (sodium hypochlorite) caused a higher microbial inactivation compared to the reference detergent (bleach-free). The intensive programme achieved a higher reduction than the short programme and the reduction in the upper basket was higher compared to the lower basket. It was discussed that the higher number of water changes, an increased mechanical action and a longer programme duration compared to the short programme caused the high mechanical removal of microorganisms in the intensive programme. The $5-\log _{10}$ reduction required by DIN SPEC 10534 has been met with the oat flake carrier for the intensive programme but was barely met by the short programme. Overall, the oat flake soil is a known test soil from the internationally established IEC 60436, easy to produce and difficult to remove from test items and, thus, suitable to produce differentiating results in combination with M. luteus DSM 1790 in water-change dishwashers [16].

An Italian study by Nicolella et al. [14] aimed to investigate the thermal sanitization of food contact surfaces in a commercial pilot tank dishwasher in order to establish the relationship between operation conditions and sanitization efficacy. Thereby, the optimal operating conditions in combination with a minimum demand of energy and water in the dishwasher should be achieved. The reduction of E. coli $\left(10^{6} \mathrm{cfu} / \mathrm{mL}\right)$ inoculated on clean glass surfaces was evaluated under different conditions of temperature and duration of the dishwashing cycles. The complete washing and rinsing cycle should deliver a minimum heat load of 3600 HUEs (heat unit equivalents) to the food contact surface to guarantee thermal sanitizing according to the American National Standard NSF/ANSI 3 [17]. The HUEs value required was not achieved in a dishwashing cycle operated under typical conditions of use (washing at $55^{\circ} \mathrm{C}$ for $40 \mathrm{~s}$ and rinsing at $85^{\circ} \mathrm{C}$ for $15 \mathrm{~s}$ ). The conditions that correspond to 3600 HUEs ensure a microbial reduction much higher than the $5-\log _{10}$ reduction required for chemical sanitizing according to NSF/ANSI 3. The microbial reduction (i.e. mechanical removal) was increased significantly with increasing water volume in the rinsing cycle, whereas the temperature of the rinsing only has a small influence on the microbial reduction. Thus, Nicolella et al. [14] concluded that the reduction was mainly caused by the mechanical removal of microorganisms from water spray jets rather than temperature. Thermal inactivation alone is not sufficient to reduce the microbial count under typical conditions (temperature, time) in commercial dishwashing. Dishwashing cycles may generally achieve a sufficient sanitizing efficacy even at lower temperatures $\left(45^{\circ} \mathrm{C}\right)$ when a high volume of water is sprayed onto the food contact surfaces during the rinsing phase, i.e. after all the soil and dirt have been removed [14].

The $\mathrm{A}_{0}$ concept has been introduced as a mathematical concept for the calculation of the thermal disinfection efficacy in order to save time, money and resources in healthcare facilities. Thus, the microbial reduction is no longer measured, but the physical energy expended (time-temperature combinations) to show whether a disinfection process is successful or not. The $\mathrm{A}_{0}$ concept was first published in EN ISO 15883 in 2005 for the sterilization of healthcare products in washer-disinfectors. The intended application of the EN ISO 15883 is the cleaning and disinfection of reusable medical devices and other articles used in medical, dental, pharmaceutical and veterinary practice. The $\mathrm{A}_{0}$ concept can also be applied in the special case where crockery and cutlery are to be disinfected in order to use them for immunologically compromised patients. The $\mathrm{A}_{0}$ value is the equivalent time in seconds at $80^{\circ} \mathrm{C}$ when using a z-value of $10^{\circ} \mathrm{C}$. However, this concept was confronted with criticism from a mathematical and microbiological point of view. The main criticism is that the $\mathrm{A}_{0}$ concept was adopted from the $\mathrm{F}_{0}$ concept without experimental validation. However, the $\mathrm{F}_{0}$ concept was developed for sterilisation processes with temperatures above $115^{\circ} \mathrm{C}$, whereas the $\mathrm{A}_{0}$ concept is valid for temperatures between $65^{\circ} \mathrm{C}$ and $95^{\circ} \mathrm{C}$. Furthermore, a generally valid z-value of $10^{\circ} \mathrm{C}$ does not exist, as it is microorganism-specific. Therefore, Buchrieser [8] aimed to evaluate the microbiological validity of the $\mathrm{A}_{0}$ concept and the recommendations of $\mathrm{A}_{0}$ values given by the Austrian Society for Sterile Supply (ÖGSV). Different time-temperature combinations resulting in the same $\mathrm{A}_{0}$ value achieved differences in the reduction of E. faecium ATCC 6057 up to $7.9 \log _{10}$ steps. The microbial reduction at lower temperatures and longer exposure times was never as effective as the reduction at higher temperatures and shorter exposure times. The $\mathrm{A}_{0}$ value of $30 \mathrm{~s}$, for instance, recommended by the ÖGSV for the disinfection of dishes seems to be sufficient only at temperatures above $80^{\circ} \mathrm{C}$. The recommended $\mathrm{A}_{0}$ of $60 \mathrm{~s}$ for the disinfection of bedpans was evaluated as too 
low since the reduction of a high number of heat resistant enterococci from human stool has to be guaranteed in this setting. Buchrieser [8] concluded that the reduction of E. faecium cannot be described with the $\mathrm{A}_{0}$ concept as it has been experimentally proven. Only $\mathrm{A}_{0}$ values $\geq 180 \mathrm{~s}$ and temperatures $\geq 75^{\circ} \mathrm{C}$ can achieve an efficient and satisfactory disinfection efficacy with a sufficient safety margin [8].

Another study by McCormick et al. [9] also intended to verify the $\mathrm{A}_{0}$ concept. It presents recent data on thermal disinfection of a range of planktonic microorganisms and mixed culture biofilms for $\mathrm{A}_{0}$ values of $60 \mathrm{~s}, 600 \mathrm{~s}$ and $3000 \mathrm{~s}$. None of the microorganisms tested reached increased levels of heat resistance with a $\geq 6$ - $\log _{10}$ reduction at $A_{0}$ values of 600 and $3000 \mathrm{~s}$. All microorganisms tested at $A_{0}$ values of $60 \mathrm{~s}$ were considerably inactivated, except the environmental isolate of $M$. luteus which showed only a $\geq 2-\log _{10}$ reduction. However, this result for M. luteus was not that surprisingly since it has been reported to be relatively thermo-tolerant. Similar results of thermo-resistance have been reported for Enterococcus and Enterobacteriaceae. Biofilm testing showed that biofilm formation did not substantially change the susceptibility of the microorganisms towards heat. All in all, McCormick et al. [9] concluded that the $\mathrm{A}_{0}$ concept should be more widely applied to verify the efficacy of most heat disinfection in washer-disinfectors and other applications. The minimum temperature for the application should be increased to at least $70^{\circ} \mathrm{C}$ or $75^{\circ} \mathrm{C}$ to take the inactivation of thermo-resistant bacteria and viruses into account [9].

\section{Overview of standards specifying hygiene requirements for commercial dishwashing}

The American standard NSF/ANSI 3 [17] (Commercial Warewashing Equipment) aims to establish minimum public health and sanitation requirements for the materials, design, construction and performance of commercial dishwashers. The performance tests are subdivided into soil removal tests and sanitization efficacy tests. The soil removal tests differ depending on the intended use of the dishwasher. The cleaning efficacy of a dry coating of buttermilk (1\% milk-fat) from the surfaces of dinner plates and glasses should be evaluated after cleaning in normal dishwashers and glass washing machines. Surfaces of plates and glasses should be free of visible soil and detergent. However, the test soiling for pot, pan and utensil washing machines consists of pie filling. The machines should have the ability to remove a baked coating of pie filling (that contains corn starch) from the surfaces of cookware [17]. The test method for sanitization efficacy tests differentiates between dishwashers that sanitize by hot water or chemical solutions. Hot water sanitizing dishwashers should reach a minimum of 3600 HUEs at the surface of dishes or pots, pans and utensils. All data points for a temperature $\geq 62^{\circ} \mathrm{C}$ are used to calculate the total HUE value. Chemical sanitizing machines must achieve a $99.999 \%$ reduction $\left(\geq 5-\log _{10}\right.$ reduction) of relevant microorganisms on the surface of dishes in the sanitizing portion of the dishwashing cycle. The interior and lip of milk glasses or hotel pans and stock pots are inoculated with a test suspension of $\geq 10^{6} \mathrm{cfu} / \mathrm{mL}$ E. coli ATCC 11229. Taken together, 105 glasses from 21 sections need to be investigated, whereas 12 pans and 3 pots need to be sampled for pot, pan and utensil washing machines [17].

The Australian Standard 4674 [18] was established in 2004 to provide standardized criteria for the hygienic design, construction and fit-out of food premises for the food industry, the construction industry and governments across Australia. Requirements for dishwashers and glasswashers are defined in Section 4. Dishwashers and glasswashers should be capable of washing and rinsing in one continuous operation. When hot water is used to sanitize, the dish-/glasswasher should only operate on the sanitizing cycle when the sanitizing water temperature is reached. Furthermore, no brushes are allowed in glasswashers for sanitizing. The temperature of the water used in the sanitizing rinse cycle combined with the time the utensils are rinsed at this temperature should be sufficient to ensure a sanitization of utensils. Here, the standard refers to the requirements given by AS 2945 for batch-type washer/disinfectors for healthcare facilities: utensils should undergo a sanitizing rinse at $80^{\circ} \mathrm{C}$ for $2 \mathrm{~min}, 75^{\circ} \mathrm{C}$ for $10 \mathrm{~min}$ or $70^{\circ} \mathrm{C}$ for $15 \mathrm{~min}$. When chemicals are used in dish or glass washing, it has to be ensured that the design of the machine allows the use of chemical sanitizers and the rinsing is able to wash off all chemical residues [18].

The Chinese GB 14934 [19] "National Food Safety Standard" specifies hygienic requirements for the disinfection of dinner and drinking sets. This standard gives technical requirements regarding sensory, physical and chemical residues and limits for microorganisms on dinner and drinking sets and provides sampling methods. The residual quantity of decontamination agents, such as chlorine $\left(\leq 0.03 \mathrm{mg} / 100 \mathrm{~cm}^{2}\right)$ or anionic synthetic detergent (not detectable), are only applicable for chemical disinfection [19].

The microbiological limits have to be determined for coliform bacteria and Salmonella. No microorganisms must be detectable on $50 \mathrm{~cm}^{2}$. Two different sampling methods are provided to detect possible bacterial residues - the fermentation method and the paper scrap method. The sampling according to the fermentation method is used for the detection of coliform bacteria and Salmonella on chop-sticks and other dinner and drinking sets. For sampling, five chop-sticks $\left(50 \mathrm{~cm}^{2}\right)$ are sampled using moistened cotton swabs. Other dinner and drinking sets are sampled in a total area of $50 \mathrm{~cm}^{2}$ also with filter papers or cotton swabs. The sampling for coliforms with the paper scrap method works as follows: Chop-sticks have to be immediately daubed with paper scrap after moistening the quick test paper scrap with normal saline. Regarding other dinner and drinking sets, the moistened quick test paper scrap has to be stuck on the inner wall surface of dinner and drinking sets (30 s) that are generally in contact with food or lips [19].

The CEN/TC 429 of the European Committee for Standardization is preparing a European standard for hygiene requirements and testing of commercial dishwashers based on DIN SPEC 10534. However, it has not yet been published [20]. The underlying pre-standard DIN SPEC 10534 summarises the standards DIN 10510 (multi-tank transport dishwashers), DIN 10511 (glass washing machines), DIN 10512 (commercial one-tank dishwashers) and DIN 10522 (reusable boxes and containers for unpackaged foodstuffs). Hygiene requirements for the planning, construction and operation of commercial dishwashers of various designs 
and types are specified within this pre-standard. In particular, information on hygienic and professional operation, cleaning and disinfection of the washware, and care and maintenance of the machines are provided. Different procedures for testing the hygienic operation and their particular area of application are described. Furthermore, principles for the proper spatial-functional arrangement within the kitchen area and the proper and hygienic organisation of the washware cycle are presented. Clean and unclean areas in the kitchen generally have to be separated in order to prevent the recontamination of clean dishes, cutlery or glasses until reprovision. The dishwasher has to be maintained regularly to guarantee functional and operational safety. DIN SPEC 10534 clearly arranges the microbiological requirements in overview tables to quickly identify the respective test procedure, test method and hygiene requirement for the test object. All types of tests (type test and/or procedure test, post-installation test, daily inspection, periodic inspection, non-routine testing) are tabulated and allow for a direct comparison of the area of application and scope of testing. Type testing is used to prove that a machine built in series meets the requirements for cleaning and disinfection. After the installation of the dishwasher, a post-installation test is performed to confirm the hygienic operating when used according to the instructions of the manufacturer. During the running operation, a procedure test helps to evaluate the hygienic functioning under practical conditions of use. The daily inspection has to be conducted by the operator to monitor hygiene-relevant parameters, such as temperature or concentration of detergent, but no microbiological assessments have to be undertaken. Routine tests periodically ensure the hygienic functioning during the running operation of the dishwashers. A non-routine test has to be executed after procedurally impaired rebuilds or changes. The scope of testing includes all test methods introduced in DIN 10510, DIN 10511, DIN 10512 and DIN 10522: visual inspection of cleanliness and dryness, temperature check, determination of surface total aerobic count on the washware, tests with bioindicators, microbiological testing of the detergent solution in the tank and testing of the water quality [25].

The contact sampling of surfaces prescribes the maximum total aerobic count on a defined area. Most of the standards define a limit of $<5 \mathrm{cfu} / \mathrm{cm}^{2}$, however, different requirements apply to reusable boxes and containers. Furthermore, the reference value for the total microbial count in the detergent and rinse aid solution is set at $200 \mathrm{cfu} / \mathrm{mL}$, whereas the alarm value is $500 \mathrm{cfu} / \mathrm{mL}$. In addition, tests with bioindicators are performed in some cases. Consequently, stainless steel bioindicators contaminated with $0.1 \mathrm{~mL}$ of a mixture of the test soiling BAMS (containing $0.6 \%$ bovine albumin, $1.0 \%$ mucin and $3.0 \%$ maize starch) and $10^{7} \mathrm{cfu} / \mathrm{mL}$ E. facium ATCC 6057 are applied in a dishwashing cycle. The acceptance criteria is a $5-\log _{10}$ reduction. The test strain E. faecium ATCC 6057 has to be checked biannually to ensure a sufficient heat resistance [25].

DIN 10510:2013-10 [21] applies to multi-tank conveyortype dishwashers with at least one prewash zone, a detergent-circulating zone and a fresh water rinsing zone. A temperature of $60^{\circ} \mathrm{C}$ is recommended in the detergent tank. The freshwater rinsing can range from $25^{\circ} \mathrm{C}$ to $85^{\circ} \mathrm{C}$. The contact time in the tanks should be at least 2 min, depending on the transport speed. Most of the types of tests (procedure test, post-installation test, daily inspection, periodic inspection, non-routine testing) apply to multi-tank conveyortype dishwashers. A type test would not be meaningful because different types of dishwashers are combined regarding the needs of the operator. Therefore, the procedure test was introduced. The post-installation test has to be conducted after the installation of the dishwashers. The total aerobic count on the surface of at least 10 dish items has to be checked with the contact sampling method. The total aerobic count of the detergent and rinse aid solution in the last tank has to be determined after $0.5 \mathrm{~h}$ of fully operating. Lastly, tests with bioindicators in special test racks and under practical conditions have to be performed. In test racks, 10 bioindicators have to reach a $5-\log _{10}$ reduction. However, only 1 out of 8 bioindicators is allowed to have a $\log _{10}$ reduction $<5$ in the cutlery rack. A half-yearly routine inspection includes surface sampling of washware items and the sampling of the detergent and rinse aid solution [21].

Higher requirements have to be followed according to DIN 10511:1999-05 [22] for glasswashing machines because the cleaning result of glasses is substantially influenced by the water quality. Softened or demineralized water has to be used to avoid deposits on the glassware. The temperature in the detergent tank has to be at least $55^{\circ} \mathrm{C}$ and $(65 \pm 2){ }^{\circ} \mathrm{C}$ in the final rinse. The temperatures for cleaning should not be much higher than $60^{\circ} \mathrm{C}$ to maintain the usability of the glasses. Contact times of at least $90 \mathrm{~s}$ are recommended. Residues from drinks are not allowed to dry on the glasses for more than $2 \mathrm{~h}$. The cleaned glasses cannot be dried or polished manually after the glass washing cycle. The microbiological assessment for glass washing machines includes the type testing, daily inspection and procedure testing. In the type test, the decontamination efficacy of two standardized test glasses contaminated with reconstituted skimmed milk and $10^{7}$ E. faecium is tested. Therefore, the shortest programme should be used in combination with $1.5 \mathrm{~g} / \mathrm{L}$ prescribed test detergent and test rinse aid. In addition to the interior, the mouth edges of the glasses are also to be contaminated and allowed to dry for $2 \mathrm{~h}$ before washing. Ninety per cent of the glasses have to reach a $5-\log _{10}$ reduction; $10 \%$ of the glasses can be below this limit. The procedure testing under practical conditions of use is recommended considering the duty of care of the operator. At least 10 glasses must undergo contact sampling, but only 1 out of 10 glasses can have more than $5 \mathrm{cfu} / 10 \mathrm{~cm}^{2}$. Moreover, the total microbial count in the detergent and rinse aid solution has to be determined [22].

DIN 10512:2008-06 [23] applies to commercial one-tank dishwashers. The temperature in the pre-clearance zone should not exceed $35^{\circ} \mathrm{C}$ to avoid the build-up of protein and starch residues. The temperature must be $60^{\circ} \mathrm{C}$ to $65^{\circ} \mathrm{C}$ in the detergent solution tank and $80^{\circ} \mathrm{C}$ to $85^{\circ} \mathrm{C}$ in the final rinse. When the detergent contains a disinfecting or oxidizing component, the temperature in the detergent tank can be reduced to $55^{\circ} \mathrm{C}$ to $65^{\circ} \mathrm{C}$. A temperature of at least $60^{\circ} \mathrm{C}$ for $90 \mathrm{~s}$ in the detergent tank is generally recommended. The drying time of food residues on the washware items should be less than $2 \mathrm{~h}$. Three different types of tests apply regarding one-tank dishwashers: type testing, procedure testing and daily inspection. However, the procedure 
testing is only recommended. The type test is performed with bioindicators in front of test plates and in the cutlery tray. The test programme should be the shortest available and $3 \mathrm{~g} / \mathrm{L}$ liquid alkaline standard detergent without active chlorine and acidic standard rinse aid should be used. Ninety per cent of the bioindicators have to achieve a $5-\log _{10}$ reduction, but all of the bioindicators have to reach a reduction above $4 \log _{10}$ steps. The procedure testing includes surface sampling of at least 10 washware items (only 1 item can have $>5 \mathrm{cfu} / 10 \mathrm{~cm}^{2}$ ) and the determination of the total aerobic count of detergent solution [23].

DIN 10522:2006-01 [24] contains hygiene requirements for washer-disinfectors used to clean and disinfect reusable boxes and containers (crates) for the storage and transport of unpacked food in the commercial sector. The type of tests and hygienic requirements are based on the hygienic risk of the transported food, which is classified into less critical, critical and very critical food. Less critical foods are, for example, fruit and vegetables, critical food can be bread and rolls, and very critical foods are meat and fish, for instance. The type of contamination on the reusable boxes and crates determines the water temperature required in the washerdisinfector. Water in the pre-clearance should not exceed $45^{\circ} \mathrm{C}$ to avoid the build-up of starch or protein residues. When a thermal disinfection is necessary, at least $60^{\circ} \mathrm{C}$ in the detergent solution and at least $80^{\circ} \mathrm{C}$ in the final rinse must be reached. If thermal disinfection is not applicable, a disinfecting or oxidizing component needs to be added to the detergent. Different types of detergents and contact times have to be applied to remove the specific contamination due to the different kinds of soil on the reusable boxes and crates. No microbiological tests are necessary for less critical reusable boxes and crates. Critical reusable boxes and crates must have surfaces with low microbiological contamination (total aerobic count $<500 \mathrm{cfu} / 100 \mathrm{~cm}^{2}$; $<20 \mathrm{cfu} / 100 \mathrm{~cm}^{2}$ for yeasts and moulds). The total aerobic count in the detergent solution also has to be determined. The strictest hygiene requirements have to be fulfilled for reusable boxes and crates used for very critical foodstuffs. No Enterobactericeae must be detected per $100 \mathrm{~cm}^{2}$. Only 2 out of 10 samples can have more than 0 but less than $10 \mathrm{cfu} / 100 \mathrm{~cm}^{2}$. The limit for the total aerobic count is further reduced to $100 \mathrm{cfu} / 100 \mathrm{~cm}^{2}$. The total aerobic count of the detergent solution also has to be determined. The acceptance level for tests with bioindicators is a $5-\log _{10}$ reduction for $90 \%$ of the bioindicators and at least a $4-\log _{10}$ reduction for the residual $10 \%$. The tests for washer-disinfectors used for reusable boxes and crates are generally type testing, post-installation tests and routine testing. The inspection frequency is based on the hygienic criticality of the foodstuff transported [24].

DIN 6653-3:2011-01 [26] addresses primarily manufacturers of glasswashers and operators of out-of-home catering facilities that serve beverages. The standard provides hygiene efficacy requirements for manual glass scrubbing devices with physically separated pre-rinsing and post-rinsing. Cleaning and disinfection have to be performed daily (when used daily), on demand, prior to the first use, after longer non-use and after repair of the manual glass scrubbing devices. Firstly, the glasses are pre-rinsed and cleaned inside and outside by scrubbing with brushes and a suitable detergent. In the second step, the glasses are post-rinsed with tap- water to remove the soil particles dissolved. However, no requirements for the water temperature are given in the standard. The water flow has to be adjusted in order to achieve a sufficient renewal of water used in the pre-rinsing step. Residues of beverages should not dry for more than $2 \mathrm{~h}$ on the glasses and the latter are not allowed to be dried or polished manually after cleaning. Two types of tests apply for manual glass scrubbing devices: daily inspection and type testing. In the daily inspection, the glasses, the glass scrubbing device and the environment of the device have to be visually clean. The type testing includes a test for visual cleanliness and dryness and one for the decontamination efficacy of the manual glass scrubbing device under defined test conditions. The glasses are contaminated on the interior and the mouth edge with reconstituted skimmed milk containing $10^{7} \mathrm{cfu}$ E. faecium ATCC 6057 per glass. If necessary, a non-pathogenic test strain can be used when it has similar characteristics to the established E. faecium. The test has to be performed with detergent recommended by the manufacturer. The acceptance criteria is the lowest compared to the other DIN standards: $90 \%$ of the glasses have to achieve a $4-\log _{10}$ reduction; $10 \%$ with lower reduction can be tolerated [26].

\section{Regulations regarding the hygiene of foodstuffs and particularly commercial dishwashing}

The Codex Alimentarius is a summary of standards for food safety and product quality of the United Nations published by the Food and Agriculture Organization and World Health Organization. It aims to protect consumers' health and ensure fair practices in the food trade [29], however, it is not directly legally binding. One aim of the Codex Alimentarius is to establish effective systems in order to ensure adequate maintenance and cleaning, control pests, manage waste and monitor effectiveness of maintenance and sanitation procedures. The cleaning should ensure that food residues and dirt are removed. If necessary, a disinfection may be performed after cleaning. For cleaning, physical methods such as heat, scrubbing, turbulent flow, vacuum cleaning and chemical methods using detergents, alkalis or acids should be applied separately or in combination. The cleaning methods include the following subsequent steps: removing gross debris from surfaces; applying a detergent solution; rinsing with water; dry-cleaning; and, where necessary, disinfecting with subsequent rinsing. The suitability and efficacy of the cleaning and disinfection procedures need to be monitored. Adequate facilities for the cleaning of food, utensils and equipment should be provided with a supply of hot and cold potable water of drinking water quality [30].

The U.S. Food and Drug Administration published the Food Code [31] providing a technical and legal basis for regulating the retail and food service. Regarding ware washing machines, the Food Code specifies requirements for the design of machines and provides technical details for cleaning and sanitization. After the cleaning, food-contact surfaces should be visually clean and free of soil. A sanitization is achieved when representative disease microorganisms of public health importance are reduced by $5-\log _{10}(99.999 \%)$ by means of hot water or chemicals. The Food Code prescribes minimum temperatures for the wash solution and hot water sanitization and provides details of the chemical 
sanitization to guarantee clean and sanitized items. Temperatures of $74^{\circ} \mathrm{C}$ (single temperature machine) and $66^{\circ} \mathrm{C}$ (dual temperature machine) are prescribed (stationary rack machines) for spray type warewashers using hot water to sanitize. One-tank, conveyor, dual temperature machines must reach at least $71^{\circ} \mathrm{C}$, whereas multi-tank, conveyor, multitemperature machines have to achieve at least $66^{\circ} \mathrm{C}$. The minimum wash solution temperature for spray type warewashers using chemicals to sanitize is $49^{\circ} \mathrm{C}$. The surfaces temperature on food-contact items must reach at least $71^{\circ} \mathrm{C}$ for an effective sanitization by means of hot water. The lower temperature limit for stationary rack, single temperature machines is $74{ }^{\circ} \mathrm{C}$ and $82^{\circ} \mathrm{C}$ for all other machines based on the sanitizing rinse contact time to achieve the prescribed $71^{\circ} \mathrm{C}$ on food-contact surfaces. Chemical sanitizing is done by the application of sanitizing chemicals by immersion, manual swabbing, brushing or pressure spraying methods, using a solution. Different contact times are specified depending on the chemicals used [31].

The European Parliament and the Council of the European Union established Regulation No. 852/2004 [32] regarding the hygiene of foodstuffs to ensure a high level of consumer protection regarding food safety. Food business operators need to comply with general and specific hygiene requirements. Suitable devices for cleaning, disinfecting and storing tools and equipment for food must be provided where necessary. These facilities must be made of corrosion-resistant materials, be easy to clean, and have adequate hot and cold water supplies. Transport and/or food handling containers should be kept clean and maintained to protect food from contamination and, where necessary, designed and constructed to allow adequate cleaning and/or sanitizing [32].

The German Food Hygiene Regulation (LMHV) regulates specific food hygiene issues and the implementation of legal acts of the European Community or the European Union in the field of food hygiene. It does not give details on the cleaning or disinfection of food-contact items, however, it requires that people handling food need to have expertise in cleaning and disinfection processes [36]. The Federal Centre for Health Education (BZgA) and the Federal Institute for Risk Assessment (BfR) aim to prevent health risks for consumers and present hygiene measures for community catering. The general requirements for the cleaning temperature and duration must be met. A sufficient amount of detergent for the cleaning of cutlery, dishes and kitchen essentials with hot water should ensure a hygienically clean result. When cleaned in the dishwasher, a temperature of at least $60{ }^{\circ} \mathrm{C}$ has to be achieved [35-37].

In addition to the BZgA and BfR, the Robert Koch Institute (RKI) gives specific and detailed information on cleaning and disinfection processes for community catering. It is the central scientific institution of the German government in the field of biomedicine and one of the most important bodies for safeguarding public health in Germany [39]. Regarding the reprocessing of care utensils, washer-disinfectors should be preferred to manual reprocessing. Shaking beakers, measuring spoons, etc., must be thermally disinfected using suitable processes (e.g. dishwashers at $\geq 60^{\circ} \mathrm{C}$ or washer-disinfectors). Dishes can be cleaned in single-tank dishwashers (household dishwashers with $65^{\circ} \mathrm{C}$ programmes). In the case of a large volume of dishes, a multi- tank dishwasher can be useful. DIN 10510 recommends once-a-year inspection using suitable bioindicators for multi-tank dishwashers in communal areas [38].

Regarding the COVID-19 pandemic, the RKI provides information on how to process dishes that may have been contaminated with the coronavirus (SARS-CoV-2). The dishes have to be transported in a closed container to the dishwasher and cleaned as usual in the hospital [39, 42, 49].

Due to the COVID-19 pandemic, the government of Germany resolved hygiene and protection measures to prevent the spread of the virus. The state-specific regulations generally summarise measures regarding the hygiene and disinfection of commercial dishwashers as follows: prescribed temperatures have to be reached to ensure a sufficient cleaning of the wash-ware [40]. Dishes and cutlery used by guests should be washed with a suitable amount of appropriate detergent at a temperature of at least $60^{\circ} \mathrm{C}$. Cleaning in the dishwasher has always to be preferred to mechanical cleaning since an average germ reduction of about $99.6 \%$ was achieved with mechanical cleaning in the dishwasher, but only $87.7 \%$ germ reduction has been achieved for manual cleaning, ranging from $69.9 \%$ to $99 \%$ [49-51]. If it is not possible to clean glasses in a dishwasher or glasswasher at $\geq 60^{\circ} \mathrm{C}$, the glasses should be cleaned manually using hot water of at least $45^{\circ} \mathrm{C}$ with detergent. If colder water is used, special attention should be paid to a sufficient amount of detergent, a longer dwell time of the glasses in the sink and thorough mechanical cleaning and subsequent drying of the glasses. The mouthpieces, hoses and water vessels in shisha bars must be cleaned with a suitable cleaning agent after each use [41, 42]. However, restaurants and bars had to be closed again due to the increasing number of infections with the coronavirus in Germany in winter 2020 [43].

\section{Market information with a focus on hygiene in commercial dishwashing in times of the coronavirus pandemic}

The German working group commercial dishwashing (AK GGS) - consisting of manufacturers of detergents, commercial dishwashers and dispensers, warewashing equipment and the associated supplier industry from all over Germany - published a practical handbook for commercial dishwashing [49] and provides therewith professional knowledge transfer in German and English [47]. Chapter 11 deals with hygiene and aims to facilitate the hygienic operation of commercial dishwashers for the provider. In addition to the compliance with general hygiene requirements for food processing (such as Regulation (EC) No.178/2002, (EC) No. 852/2004 and DIN 10516), there is a large number of special features to be taken into account for commercial dishwashing, which are recorded and explained in DIN standards. The practical handbook of the AK GGS summarises the existing DIN standards (DIN 10510, DIN 10511, DIN 10512, DIN 10522 and DIN SPEC 10534) for the different types of commercial dishwashers [46].

In Austria, the ÖGSV specifies instructions for testing the cleaning and disinfection efficacy of warewashers used in commercial kitchens and the healthcare sector (Guideline No. 12). The tests should be conducted after the installation (post-installation test) and periodically during operating (periodic inspection), including the testing of cleaning 
efficacy and a temperature control. Further test methods need to be performed for non-thermal processes: the reduction of the total microbial count needs to be verified, the final rinse water needs to be tested microbiologically, the surface of the washware needs to be tested using contact cultures and, if necessary, the dosing precision needs to be verified [33].

The cleaning efficacy is performed with a test soiling media (mixture of potato starch, flour paste, nigrosine and egg) that contaminated at least 20 washware items representing the typical routine load. After cleaning, the items are checked visually for soil residues. The acceptance criteria for the post-installation test is no visible soil and a maximum of $10 \%$ of the surface of the washware items can have small punctuate residues for the periodic inspection [33].

The temperature in the final rinse must be $\geq 80^{\circ} \mathrm{C}$. Different time-temperature combinations can be applied for thermal disinfections to achieve a sufficient result $\left(\geq 80^{\circ} \mathrm{C}\right.$ for $\geq 30 \mathrm{~s}, \geq 83^{\circ} \mathrm{C}$ for $\geq 15 \mathrm{~s}, \geq 85^{\circ} \mathrm{C}$ for $\geq 10 \mathrm{~s}$ ). Machines using the $\mathrm{A}_{0}$ concept have to reach an $\mathrm{A}_{0} \geq 30 \mathrm{~s}$ for temperatures $\geq 80^{\circ} \mathrm{C}$ [33].

The total microbial count reduction should be tested with bioindicators. At least three bioindicators contaminated with organic soil (e.g. BAMS acc. to DIN 10510) and $10^{5}$ to $10^{6} \mathrm{cfu} / \mathrm{mL}$ E. faecium per test run should be attached to the washware (e.g. cutlery basket) and tested in the warewasher. The acceptance criteria is a $5-\log _{10}$ reduction. In addition to tests with bioindicators, the final rinse water should be sampled for any recontamination if the final rinse temperature is below $80^{\circ} \mathrm{C}$. The total microbial count in the final rinse water must be $\leq 100 \mathrm{cfu} / \mathrm{mL}$ and no Pseudomonas aeruginosa should be detectable in $100 \mathrm{~mL}$ for multi-tankand one-tank dishwashers. The additional requirement that E. faecium has not been detected in $100 \mathrm{~mL}$ applies to waterchange dishwashers. In the case where sampling of the final rinse water cannot be performed, the surface of two washware items can be checked for contamination using contact cultures. The limit for contact cultures is $<5 \mathrm{cfu} / 20 \mathrm{~cm}^{2}$ and no Pseudomonas aeruginosa should be detectable. The last test method is contact culturing from washware items after the completion of the test run. At least five washware items that have been cleaned in the same cycle as the bioindicators need to be sampled. Contact culture sampling can be omitted for thermal processes with final rinse temperatures above $80^{\circ} \mathrm{C}$. The acceptance criteria for contact cultures is $<5 \mathrm{cfu} / 20 \mathrm{~cm}^{2}$. The test strain E. faecium and Pseudomonas aeruginosa must not be detectable [33].

In times of the coronavirus pandemic, manufacturers of cleaning products, such as etol ${ }^{\oplus}$ or Dr. Weigert, provide information about a hygienic operation regarding SARS-CoV-2 and the AK GGS published a fact sheet about commercial dishwashing and SARS-CoV-2. The AK GGS emphasises that the manual cleaning of drinking glasses has disadvantages in comparison to the standardized machine cleaning with higher temperatures, longer contact times, and constant mechanics and detergent dosage [49].

etol ${ }^{\circledast}$ supports customers with solutions in the areas of cleanliness and hygiene, healthcare and pharmaceutical products, and plastics technology. It recommends that the specifications of the RKI are followed for commercial dishwashing in times of the coronavirus. The RKI recommends that dishes of people affected should be transported to the dish- washer in a closed container and cleaned as in hospitals. The machines in hospitals and other facilities where commercial dishwashers are used should be operated in accordance with the DIN standards for commercial dishwashing (DIN 10510, DIN 10511 and DIN 10512). The temperature in the detergent tank should be between $60^{\circ} \mathrm{C}$ and $65^{\circ} \mathrm{C}$ if a detergent without a disinfection component is used. If a detergent with a disinfection component is used, the temperature can be reduced to $55^{\circ} \mathrm{C}$ to $65^{\circ} \mathrm{C}$. For rinsing, $80^{\circ} \mathrm{C}$ to $85^{\circ} \mathrm{C}$ is recommended. The detergents from etol ${ }^{\circledast}$ are highly alkaline and lead to hygienically clean rinsing results. The contact time, i.e. the duration of a rinse cycle, should be at least 2 min for a commercial multi-tank dishwasher. In a one-tank dishwasher, on the other hand, $90 \mathrm{~s}$ is sufficient to achieve the best possible hygienic results [44].

Dr. Weigert is a German company developing professional system solutions in machine cleaning and disinfection in laboratory and medical technology, in the commercial kitchen sector and in the pharmaceutical, cosmetics and food industries. Regarding the cleaning of dishes and cutlery in times of the coronavirus (SARS-CoV-2), it recommends cleaning dishes and cutlery in the dishwasher at temperatures $>60^{\circ} \mathrm{C}$ and refers to the recommendations of the RKI [45]. The information from manufacturers of cleaning products on the coronavirus does not claim to be complete.

\section{Conclusion}

Cleaning and disinfection processes in commercial dishwashing are mainly influenced by temperature, time, chemistry and mechanics. Scientific studies provide insights into the interaction of those parameters in different commercial dishwashing settings (i.e. tank dishwashers and waterchange dishwashers) and contribute to extending the state of knowledge constantly. Existing cleaning methods in commercial dishwashing are based on the well-established chemo-thermal inactivation and mechanical removal of microorganisms. The main conclusions drawn from studies regarding the influence of temperature, chemistry and mechanics on microbial reduction are summarised in Table 3.

Classifying the studies into Bloomfield's hierarchy for hygiene procedure testing, only one study tested the thermal disinfection efficacy within suspension tests (stage 1) [3]. Buchrieser [8] checked the microbiological validity of the $\mathrm{A}_{0}$ concept, first published in DIN EN ISO 15883 in 2005 . He found that the inactivation of E. faecium cannot be described with the $\mathrm{A}_{0}$ concept as has been experimentally proven. Different temperature-time combinations do not lead to equivalent disinfection results. Only $\mathrm{A}_{0}$ values $\geq 180 \mathrm{~s}$ and temperatures $\geq 75^{\circ} \mathrm{C}$ can achieve an efficient and satisfactory disinfection efficacy. The condition of the utensils to be disinfected, especially the soil in which the microorganisms are embedded, plays a crucial role for thermal inactivation [8].

A stage 2 study by McCormick et al. [9] supported the conclusions from Buchrieser [8] and recommended applying the $\mathrm{A}_{0}$ concept only above temperatures of $70^{\circ} \mathrm{C}$ to $75^{\circ} \mathrm{C}$ to take the inactivation of thermos-resistant bacteria and viruses into account.

However, most of the studies have to be classified into stage 3 according to Bloomfield et al. [3] since they test the 
efficacy of products and processes under conditions of use and define a microbiological limit to be achieved.

In the 1990 s, some studies $[2,10-13]$ provided the basis for the development of standards for different types of commercial dishwashers (DIN 10510, DIN 10511, DIN 10512, DIN 10522 and DIN SPEC 10534) in Germany. Hygienically clean washware can be produced when the cleaning solution in the last tank of tank dishwashers before rinsing has a total aerobic count $<100 \mathrm{cfu} / \mathrm{mL}$; bioindicators contaminated with the test soiling medium bovine albumin, mucin and corn starch and $10^{7} \mathrm{cfu}$ E. faecium are reduced by $5-\log _{10}$ steps and contact sampling of surfaces results in $<5 \mathrm{cfu} / 10 \mathrm{~cm}^{2}$. Several studies [1, 15-16] also demonstrated the suitability of the non-pathogenic M. luteus DSM 1790 (ATCC 10240) as a substitute for E. faecium since it has a similar thermotolerance. One key finding from the studies is that temperatures above $60^{\circ} \mathrm{C}$ are efficient to remove germs from washware when the contact time is $2 \mathrm{~min}$. A concentration of $10 \mathrm{ppm}$ active chlorine in the detergent ensures a hygienically clean result when the temperature is below $60^{\circ} \mathrm{C}$ in the cleaning tank. Long contact times can increase the microbial reduction; however, they cannot fully replace a chemical disinfection, especially at lower temperatures. However, the antimicrobial efficacy of the parameters tested has not been proved in stage 1 suspension tests or subsequent stage 2 surface tests, and the authors of the studies do not refer to possible studies proving the antimicrobial efficacy of temperature, contact time, detergent or bleach, or mechanical removal.

In addition to the most important parameters of temperature, time and chemistry, a study from Nicolella et al. [14] has found that the microbial reduction is mainly caused by mechanical action of water spray jets rather than temperature. Thus, thermal inactivation alone is not sufficient enough to reduce the microbial count under typical conditions (temperature, time) in a commercial dishwasher. A suffi- cient sanitizing efficacy can be attained even at lower temperatures $\left(45^{\circ} \mathrm{C}\right)$ when a high volume of water is sprayed onto the dishes during the rinsing phase. However, this study was performed with $10^{6} \mathrm{cfu} / \mathrm{mL}$ Escherichia coli without soiling, which makes it difficult to evaluate the microbial reduction under aggravated conditions (e.g. with persistent soil residues).

More recent studies from Kerschgens et al. [15] and Klapper et al. [1] have proven the use of the non-pathogenic Micrococcus luteus DSM 1790 (ATCC 10240) in water-change dishwashers as an alternative test strain to the established E. faecium ATCC 6057 since it has a comparable heat resistance. The M. luteus strain can be used in usual dishwashing laboratories due to its belonging to Biosafety level $1[1,15]$.

Zinn et al. [16] performed tests with $M$. luteus on bioindicators contaminated with oat flakes instead of BAMS. The oat flake soil is easy to produce, difficult to remove from test items, suitable to produce differentiating results and could, thus, be an alternative to BAMS when testing commercial water-change dishwashers [16].

The study from Zinn et al. [16] supports, furthermore, the finding from Nicolella et al. [14] that the mechanical washing off is a parameter not to be underestimated. Intensive programmes with a higher number of water changes, increased mechanical action and longer programme duration lead to higher reductions compared to short programmes. The most widely used bleach component in the detergent (sodium hypochlorite) increases the microbial reduction in comparison to bleach-free detergents [16].

Recommendations specifying hygiene requirements for commercial dishwashers are not available in all parts of the world. The existing standards are country-specific and a compliance with them is not obligatory. Germany, Europe, China, Australia and the USA have established standards including requirements for the construction and design of

\begin{tabular}{|c|c|c|c|}
\hline & Thermal inactivation & Chemical inactivation & Mechanical removal \\
\hline Time & $\begin{array}{l}\text { - Temperatures }>60^{\circ} \mathrm{C} \text { for } 2 \text { min } \\
\text { achieve sufficient hygiene [13-15] } \\
\text { - Higher temperatures are always more } \\
\text { effective than lower temperatures } \\
\text { (even at longer contact times) [8] } \\
\text { - Intensive programme (with higher tem- } \\
\text { peratures) more effective than short } \\
\text { programme [16] } \\
\text { - Minimum temperature for application } \\
\text { of } A_{0} \text { about } 75^{\circ} \mathrm{C}[8-9] \\
\text { - Increase of cleaning temperature has a } \\
\text { higher antimicrobial effect than an in- } \\
\text { crease of rinsing temperature [15] }\end{array}$ & & $\begin{array}{l}\text { - Longer contact times (longer contact } \\
\text { with cleaning solution, increased me- } \\
\text { chanical removal, higher number of } \\
\text { water changes) increases microbial re- } \\
\text { duction compared to shorter pro- } \\
\text { grammes }[11,16]\end{array}$ \\
\hline Temperature & & $\begin{array}{l}\text { - Temperatures }>60^{\circ} \mathrm{C} \text { and chlorine } \\
\text { content }>10 \text { ppm achieves sufficient } \\
\text { antimicrobial effect [10] } \\
\text { - At temperatures }>60^{\circ} \mathrm{C} \text {, even a low } \\
\text { concentration of active chlorine \& alka- } \\
\text { line pH are highly antimicrobial [10] } \\
\text { - Temperatures }>60^{\circ} \mathrm{C} \text {, a concentration } \\
\text { of } 10 \mathrm{ppm} \text { chlorine achieves sufficient } \\
\text { reduction [13] } \\
\text { - Lower temperatures }\left(50^{\circ} \mathrm{C}\right) \text { and use of } \\
\text { detergents without active chlorine lead } \\
\text { to reduced microbial reduction [2] }\end{array}$ & $\begin{array}{l}\text { - High mechanical action is needed to } \\
\text { remove microorganisms (thermal inac- } \\
\text { tivation solely not sufficient enough); } \\
\text { rinsing temperature has only a small } \\
\text { impact compared to water volume [14] } \\
\text { - Soiling has a crucial impact on removal } \\
\text { of microorganisms (persistent soiling } \\
\text { requires higher temperature } \\
\text { (i.e. BAMS }>65^{\circ} \mathrm{C} \text { ) for sufficient reduc- } \\
\text { tion [2] } \\
\text { - Formation of biofilms do not change the } \\
\text { susceptibility of microorganisms towards } \\
\text { heat significantly [9] }\end{array}$ \\
\hline
\end{tabular}

Table 3 Microbial reduction classified by impact of temperature, chemistry and mechanics (as a function of time and temperature, respectively). 
commercial dishwashers or washer-disinfectors and their decontamination efficacy, and provide corresponding test methods. Even if the principle of hygiene testing in the standards mentioned is the same, the test methods differ from standard to standard. The standards require the washware to be clean (and dry), however, a method for measuring the soil removal is included only in the American NSF/ANSI 32019. The other standards only assess the cleanliness of the washware visually. However, it should be noted that separated standards for assessing the cleaning efficacy may exist (e.g. IEC 63136:2019 for tank dishwashers [52]). In addition, the standards use different test strains to assess the microbial reduction in the dishwashing process. In addition to that, the test strains are embedded in different test soiling media whose removal behaviour is not completely comparable. Standards in Germany and Europe are based on tests with bioindicators contaminated with BAMS and E. faecium or other test soiling media and test strains according to their application. The NSF/ANSI 3 uses cultured buttermilk with $10^{6}$ cfu E. coli ATCC 11229 on washware items. Many studies $[2,12,16,27-28]$ have shown that the soil matrix has a crucial influence on the cleaning result and the removal and inactivation of microorganisms. The recommended temperatures in those standards is above $60^{\circ} \mathrm{C}$ for cleaning, whereas the rinsing temperature for sanitizing is higher depending on the standard given. The German DIN standards recommend $60^{\circ} \mathrm{C}$ in the detergent tank for 90 to $120 \mathrm{~s}$ and $80^{\circ} \mathrm{C}$ to $85^{\circ} \mathrm{C}$ in the final rinse for tank dishwashers $[21,23$, 24]. The American NSF/ANSI 3 [17] standard requires mini- mum temperatures of $66^{\circ} \mathrm{C}$ to $74^{\circ} \mathrm{C}$ for cleaning and $74^{\circ} \mathrm{C}$ to $82^{\circ} \mathrm{C}$ for the sanitizing rinse according to the type of dishwasher.

The American Food Code [31] and the Australian Standard AS 4674-2004 [18] only recommend minimum temperatures for cleaning or sanitizing, but they do not provide test procedures to assess the hygiene efficacy. A worldwide standardized test method would guarantee the comparability of test results. However, country-specific conditions (such as typical washware items, e.g. chop-sticks in China) could thereby be neglected. Table 4 compares the most relevant parameters of the different country-specific standards existing.

In addition to standards, legally binding regulations and advisory guidelines are also available in some countries. Most of them contain only general rules about the hygiene of foodstuffs or cleaning and disinfection. In Germany, the RKI, BZgA or BfR provide information and give recommendations to safeguard public health. It is commonly agreed within these institutions that a dishwashing temperature of $60^{\circ} \mathrm{C}$ is sufficient for a hygienically clean result - even in times of the coronavirus (SARS-CoV-2). In Austria, the ÖGSV provides detailed information for testing commercial warewashers based on DIN standards for different types of commercial dishwashers or washer-disinfectors with only some modifications.

In the USA, the Food Code provided by the Food and Drug Administration is not federal law, but it gives detailed recommendations for minimum temperatures in dishwashers using hot water or chemical sanitizing. A key re-

\begin{tabular}{|c|c|c|c|c|}
\hline & $\begin{array}{c}\text { Germany/Europe: } \\
\text { DIN 10510-10522; DIN SPEC } \\
10534\end{array}$ & China: GB 14934-2016 & USA: NSF/ANSI 3-2019 & $\begin{array}{c}\text { Australia: } \\
\text { AS 4674-2004 }\end{array}$ \\
\hline Type of tests & $\begin{array}{l}\text { - Type test } \\
\text { - Post-installation test } \\
\text { (Daily inspection, periodic } \\
\text { inspection, non-routine } \\
\text { testing) }\end{array}$ & $\begin{array}{l}\text { - Test for coliform bacteria } \\
\text { and Salmonella }\end{array}$ & $\begin{array}{l}\text { - (Soil removal test) } \\
\text { - Sanitization efficacy test (by } \\
\text { hot water or chemical) }\end{array}$ & - None \\
\hline Test methods & $\begin{array}{l}\text { - Visual inspection (cleanli- } \\
\text { ness, dryness) } \\
\text { - Temperature check } \\
\text { - Determination of aerobic } \\
\text { microorganism count on } \\
\text { washware surface } \\
\text { - Tests with bioindicators } \\
\text { - Microbiological testing of } \\
\text { the detergent solution } \\
\text { - Water quality check }\end{array}$ & $\begin{array}{l}\text { - Inspection on sensory, } \\
\text { physical and chemical resi- } \\
\text { dues } \\
\text { - Limits for microorganisms } \\
\text { on chop-sticks/dinner and } \\
\text { drinking sets (fermentation } \\
\text { methods/paper scrap } \\
\text { method) }\end{array}$ & $\begin{array}{l}\text { - Visual inspection (cleanli- } \\
\text { ness, free from detergent) } \\
\text { - Tests with contaminated } \\
\text { washware items }\end{array}$ & - None \\
\hline Test strain & - E. faecium ATCC 6057 & - None & - E. coli ATCC 11229 & - None \\
\hline Soiling & $\begin{array}{l}\text { - BAMS on bioindicators } \\
\text { - Reconstituted skimmed } \\
\text { milk on glasses }\end{array}$ & - None & $\begin{array}{l}\text { - Cultured butter milk (1 \% } \\
\text { fat) on milk glasses, pots } \\
\text { and pans }\end{array}$ & - None \\
\hline $\begin{array}{l}\text { Recommendation } \\
\text { (time/temperature) }\end{array}$ & $\begin{array}{l}\text { - } 60 \mathrm{C} \text { in detergent tank (for } \\
90 \mathrm{resp} .120 \mathrm{~s} \text { ) } \\
\text { - } 80-85^{\circ} \mathrm{C} \text { for fresh water } \\
\text { rinse }\end{array}$ & - None & $\begin{array}{l}\text { - Minimum temperature: } \\
\text { cleaning } 66-74^{\circ} \mathrm{C} \text {, sanitizing } \\
\text { rinse } 74-82^{\circ} \mathrm{C} \text { (acc. to type } \\
\text { of dishwasher) }\end{array}$ & $\begin{array}{l}\text { - } 80^{\circ} \mathrm{C} / 2 \mathrm{~min} \text { or } \\
75^{\circ} \mathrm{C} / 10 \mathrm{~min} \text { or } \\
70^{\circ} \mathrm{C} / 15 \mathrm{~min}\end{array}$ \\
\hline $\begin{array}{l}\text { Hygiene level } \\
\text { requirement }\end{array}$ & $\begin{array}{l}\bullet \geq 5-\log _{10} \text { reduction on } \\
\text { bioindicators } \\
\text { - }<500 \mathrm{cfu} / \mathrm{mL} \text { in detergent } \\
\text { solution } \\
\text { - }<5 \mathrm{cfu} / 10 \mathrm{~cm}^{2} \text { on wash- } \\
\text { ware surface }\end{array}$ & $\begin{array}{l}\text { - Salmonella and coliform } \\
\text { bacteria not detectable per } \\
50 \mathrm{~cm}^{2}\end{array}$ & $\begin{array}{l}\text { - Hot water sanitization: } \\
3600 \text { HUEs } \\
\text { - Chemical sanitization: } \\
\left.\text { 99.999\% ( } \geq 5-\log _{10}\right) \\
\text { reduction }\end{array}$ & - None \\
\hline
\end{tabular}

Table 4 Comparative summary of country-specific standards for hygiene requirements in commercial dishwashing 


\begin{tabular}{|c|c|c|c|c|}
\hline & Germany & USA: FDA Food Code & $\begin{array}{l}\text { Europe: } \\
\text { No. } 8524 / \\
2004\end{array}$ & $\begin{array}{l}\text { International: } \\
\text { Codex } \\
\text { Alimentarius }\end{array}$ \\
\hline Type of tests & - None & - Temperature control & \multirow{6}{*}{\multicolumn{2}{|c|}{$\begin{array}{l}\text { - Food business operators need to } \\
\text { comply with general and specific } \\
\text { hygiene requirements }\end{array}$}} \\
\hline Test methods & - None & - Visual inspection of cleanliness & & \\
\hline Test strain & - None & - None & & \\
\hline Soiling & - None & - None & & \\
\hline $\begin{array}{l}\text { Recommendation } \\
\text { (time/ } \\
\text { temperature) }\end{array}$ & $\begin{array}{l}\cdot \geq 60^{\circ} \mathrm{C} \text { in the } \\
\text { dishwasher }\end{array}$ & $\begin{array}{l}\text { Wash solution temperature: } \\
\text { - Spray type warewashers using hot water to sanitize: } 66^{\circ} \mathrm{C} \\
\text { to } 74^{\circ} \mathrm{C} \text { (according to type of dishwasher) } \\
\text { - Spray type warewashers using chemicals to sanitize } \geq 49^{\circ} \mathrm{C} \\
\text { Chemical sanitizing: } \\
\text { - } 10 \mathrm{~s} \text { for a chlorine solution; or } \geq 7 \mathrm{~s} \text { for a chlorine solution of } \\
50 \mathrm{mg} / \mathrm{L}\left(\mathrm{pH} \leq 10 \text { and } \geq 38^{\circ} \mathrm{C} \text { or } \mathrm{pH} \leq 8 \text { and } \geq 24^{\circ} \mathrm{C} \text { ); or }\right. \\
\geq 30 \mathrm{~s} \text { for other chemical sanitizing solutions; or a contact } \\
\text { time with a combination of temperature, concentration, and } \\
\mathrm{pH} \text { that achieves sanitization }\end{array}$ & & \\
\hline $\begin{array}{l}\text { Hygiene level } \\
\text { requirement }\end{array}$ & & $\begin{array}{l}\text { - 5-log } 10 \text { reduction ( } 99.999 \%) \text { of representative disease } \\
\text { microorganisms of public health importance }\end{array}$ & & \\
\hline
\end{tabular}

Table 5 Comparative summary of country-specific regulations for hygiene requirements for commercial dishwashing

quirement is that the surface temperature on food-contact items must be $\geq 71^{\circ} \mathrm{C}$ for an effective sanitization by the means of hot water - realised by different water temperatures according to the respective type of machine.

The international Codex Alimentarius of the United Nations provides requirements for maintenance and sanitation to facilitate the effective control of food hazards, pests and other agents likely to contaminate food. Table 5 gives a comparative overview of the regulations presented.

Some manufacturers of cleaning products or equipment in the market of commercial dishwashing provide information on the efficacy of their products to remove the coronavirus (SARS-CoV-2). However, most of them only refer to existing standards to ensure a sufficient removal of the virus since it is not yet available for testing [48, 49].

Overall, the test procedures and recommendations for cleaning and disinfection in commercial dishwashers are country-specific but are working on the same principle. A worldwide standardized test method would facilitate the application of the standards and the results gained would be comparable. However, the current state of knowledge does not allow for a unified test procedure. Therefore, the definition of hygiene target levels according to Bloomfield et al. [3] may be a promising approach. The hygiene target levels can then be achieved using different cleaning and disinfection procedures (or a combination of different procedures). With it, the consumption of resources such as energy or water could be minimised and the safety that comes with hygienically clean washware items that proved to ensure a reduced infection rate could be maximised [3].

Most of the standards require a $5-\log _{10}$ reduction of bacteria, however, no hygiene target level is defined. A $5-\log _{10}$ reduction may be sufficient when the initial count is $10^{6}$ or $10^{7} \mathrm{cfu}$ (as is prescribed in most of the test methods), but it may too low when the initial count is much higher. A hygiene target level of $<5 \mathrm{cfu} / 10 \mathrm{~cm}^{2}$ for the surface of washware items is often prescribed. This limit is evaluated using contact cultures, but they are only a rough estimate of the microbial load on washware items. Even though the hygiene target levels might be sufficient to reduce or avoid infections, it has not been proven in intervention studies (stage 4 according to Bloomfield et al. [3]). These intervention studies are expensive and time-consuming. However, once a sufficient hygiene target level is defined, it can be applied to all types of commercial dishwashers and the operation can be adjusted to ensure this level. It is remarkable that most of the studies are stage-3 studies performed under conditions of use, without proving the antimicrobial efficacy in suspension and surface tests (stage 1 and 2) beforehand. However, the lack of stage 4 intervention studies shows that defined hygiene levels or recommendations are not proven to reduce infections under realistic conditions and can only be considered as an estimation.

\section{Acknowledgements}

The authors would like to thank Winterhalter and Miele a Cie. KG for providing relevant information.

\section{References}

1. Klapper, D., Zinn, M.-K., Schulze Struchtrup, S., von Esmarch-Rummler, B., and Stamminger, R.: Micrococcus luteus - An alternative test germ for testing the hygienic performance of commercial freshwater dishwashers. Tenside Surf. Det. 55 (2018) 369-375. DOI:10.3139/113.110578

2. Krüger, S. and Zschaler, R.: Hygienic status of drinking glasses. Hyg. Med, 25 (2000) 464-468. DOI:10.1080/02508060008686854

3. Bloomfield, S. F., Exner, M., Signorelli, C., Nath, K. J. and Scott, E. A.: The infection risks associated with clothing and household linens in home and everyday life settings, and the role of laundry. IFH. (2011) 1-43. URL: https://www.ifhhomehygiene.org/review-best-practice/infection-risksassociated-clothing-andhousehold-linens-home-and-everyday-life.

4. Robert Koch Institute: Grundwissen Antibiotikaresistenz. URL: https://www. rki.de/DE/Content/Infekt/Antibiotikaresistenz/Grundwissen/Grundwissen inhalt.html (Accessed 5 January 2021).

5. World Health Organization: Pandemie der Coronavirus-Krankheit (COVID-19). URL: https://www.euro.who.int/de/health-topics/health-emergencies/coronavirus-covid-19 (Accessed 14 January 2021). 
6. Bloomfield, S. F., Carling, P. C. and Exner, M.: A unified framework for developing effective hygiene procedures for hands, environmental surfaces and laundry in healthcare, domestic, food handling and other settings. GMS Hyg. Infect. Control 12 (2017) 2196-5226.

7. Rüdenauer, I., Blepp, M., Brommer, E., Gensch, C.-O., Graulich, K., Mudgal, S., Cervantes, R., Faninger, T., Lyons, L. and Seifried, D.: Preparatory Studies for Eco-design Requirements of Energy-using Products. Lot 24: Professional Washing Machines, Dryers and Dishwashers. Tender No. TREN/D3/91 - 2007. Final Report, Part: Dishwashers. Task 1: Definition. Öko-Institut e. V. Institute for Applied Ecology, Germany, BIO Intelligence Service, France, Büro Ö-Quadrat, Germany (February 2011).

8. Buchrieser, N.: Praxisbezug und Grenzen des bei der Desinfektion von Medizinprodukten angewandten A -Konzeptes, Masterarbeit, Institut für molekulare Biowissenschaften, Karl-Franzens-Universität Graz (2014)

9. McCormick, P. J., Schoene, M. J., Dehmler, M. A. and McDonell, G.: Moist Heat Disinfection and Revisiting the $\mathrm{A}_{0}$ concept. Biomedical Instrumentation and Technology 50 (2016) 19-26. PMid:27100072;

DOI:10.2345/0899-8205-50.s3.19

10. Sonntag, H.-G., Bansemir, K., Birnbaum, A., Fingerhut, O., Geiss, H. K., Höller, C., Hüster, R., Krüger, S., Mandler, G., Martiny, H., Schmidt, W., Vetter, K. and Zschaler, R.: Investigations of the control of conveyor belt dishwashing machines. Zentr. Steril. 1 (1993) 33-40.

11. Höller, C., Bansemir, K., Birnbaum, A., Fingerhut, O., Hüster, R., Krüger, S., Mandler, G., Martiny, H., Schmidt, W., Sonntag, H.-G., Vetter, K., and Zschaler, R.: Investigations on the control of multiple tank conveyor belt dishwashing machines: Part 2 of the cooperative study. Zentr. Steril. 4 (1993) 239-249.

12. Krüger, S., Geiss, K. H., Höller, C., Hüster, R., Mandler, G., Martiny, H., Meyer, B., Meincke, M., Schmidt, W., Sonntag, H.-G., Vetter, K. and Zschaler, R.: Investigations on monitoring the hygienic operation of multiple tank conveyor belt dishwashing machines: Part 3 of the cooperative study. Zentr. Steril. 3 (1995) 13-20.

13. Krüger, S. and Zschaler, R.: Monitoring of the decontamination action in multiple tank dishwashing machines. Hyg. Med. 21 (1996) 70-78.

14. Nicolella, C., Casini, B., Rossi, F., Chericoni, A. and Pardini, G.: Thermal sanitizing in a commercial dishwashing machine. J. Food Saf. 31 (2011) 81 -90. DOl: 10.1111/j.1745-4565.2010.00270.x

15. Kerschgens, S., Artelt, J., Brychcy, K. A., von Esmarch-Rummler, B. and Stamminger, R.: Hygienic performance of commercial dishwashers with waterchange system - An experimental study. Tenside Surf. Det. 53 (2016) 553 560. DOI: $10.3139 / 113.110459$

16. Zinn, M.-K., Klapper, D., von Esmarch-Rummler, B. and Bockmühl, D.: Development of a test method for analyzing the hygienic performance of commercial dishwashers operating on the fresh water principle. Tenside Surf. Det. 55 (2018) 376-382. DOI 10.3139/113.110579. DOI:10.3139/113.110579

17. NSF International: NSF/ANSI 3-2019 - NSF International Standard/American National Standard for Food Equipment - Commercial Warewashing Equipment. Ann Arbor, Michigan (2019).

18. Standards Australia: Australian Standard ${ }^{\mathrm{TM}}$ : AS 4674-2004 - Construction and Fit Out of Food Premises, Standards Australia International, Sydney (2004)

19. The National Health and Family Planning Commission of the People's Republic of China: National Standard of the People's Republic of China: GB 14934-2016: National Food Safety Standard Disinfection of Dinner and Drinking Set (2016).

20. CEN/TC 429 "Project Committee 106 - Food Hygiene - Dishwashing Machines - Hygiene Requirements and Testing": prEN 2015: Commercial Dishwashing Machines - Hygiene Requirement and Testing. European Standard (working document) (2020)

21. Deutsches Institut für Normung e. V.: DIN 10510:2013- 10: Food Hygiene Commercial Dishwashing with Multitank-Transportdishwashers - Hygiene Requirements, Procedure Testing, Beuth Verlag, Berlin (2013) DOl: $10.31030 / 2056267$

22. Deutsches Institut für Normung e. V.: DIN 10511 - 1999-05: Food Hygiene Commercial Glasswashing with Glasswashing Machines - Hygiene Requirements, Testing, Beuth Verlag, Berlin (1999). DOl:10.31030/8103544

23. Deutsches Institut für Normung e. V.: DIN 10512:2008-06: Food Hygiene Commercial Dishwashing with Onetank-Dishwashers - Hygiene Requirements, Type Testing, Beuth Verlag, Berlin (2008). DOI:10.31030/1406684

24. Deutsches Institut für Normung e. V.: DIN 10522:2006-01: Food Hygiene Commercial Cleaning of Reusable Boxes and Reusable Containers for Unpackaged Foodstuffs - Hygiene Requirements, Testing, Beuth Verlag, Berlin (2006). DOI: $10.31030 / 9656360$

25. Deutsches Institut für Normung e. V.: DIN SPEC 10534:2019-02: Food Hygiene - Commercial Dishwashing - Hygiene Requirements, Testing, Beuth Verlag, Berlin (2019). DOI:10.31030/3016249

26. Deutsches Institut für Normung e. V: DIN 6653-3:2011 -01: Beverage Dispensing Systems - Accessories - Part 3: Performance Requirements for Manual Glass Scrubbing Devices with Physically Separated Pre-rinsing and Postrinsing, Beuth Verlag, Berlin (2011). DOI:10.31030/1725576

27. Amberg, C.: Microbial reduction in low temperature dishwashing. Tenside Surf. Det. 55 (2018) 383-390. DOI:10.3139/113.110580

28. Brands, B., Schulze Struchtrup, S., Stamminger, R. and Bockmühl, D. P.: A method to evaluate factors influencing the microbial reduction in domestic dishwashers. J. Appl. Microbiol. 128 (2020) 1324-1338. PMid:31872930; DOI: $10.1111 /$ jam.14564

29. Food and Agriculture Organization of the United Nations: About Codex Alimentarius. URL: http://www.fao.org/fao-who-codexalimentarius/about-codex/ en/\#c453333 (Accessed 9 February 2021).
30. Joint FAO/WHO Codex Alimentarius Commission: Codex Alimentarius - General Principles of Food Hygiene. Food and Agriculture Organization of the United Nations and World Health Organization, Rome (2003).

31. U.S. Food \& Drug Administration: Food Code 2017: Recommendations of the United States Public Health Service. Content current as of 12/23/2019.

32. European Parliament and Council of the European Union: Regulation (EC) No 852/2004 of the European Parliament and of the Council of 29 April 2004 on the Hygiene of Foodstuffs. Official Journal of the European Communities L $139 / 1$ (2004)

33. Austrian Society for Sterile Supply: Guideline (No. 12) for Testing/Inspection of the Warewashers/Dishwashers Used in Commercial Kitchens as well as in Kitchens in the Healthcare Sector and Similar Communal Catering Establishments. Graz (2018)

34. Bundesministerium der Justiz und für Verbraucherschutz sowie des Bundesamts für Justiz: Lebensmittelhygiene-Verordnung in der Fassung der Bekanntmachung vom 21. Juni 2016 (BGBI. I S. 1469), die durch Artikel 2 der Verordnung vom 3. Januar 2018 (BGBI. I S. 99) geändert worden ist (2018)

35. Bundesinstitut für Risikobewertung \& Bundesanstalt für Landwirtschaft und Ernährung: Hygieneregeln in der Gemeinschaftsgastronomie. Aktualisierte Fassung, Berlin und Bonn, 2020. URL: http://www.bfr.bund.de/cm/350/hygieneregeln-in-der-gemeinschaftsgastronomie-deutsch.pdf (Accessed 12 February 2021)

36. Federal Centre for Health Education: Hygienetipps - Küchen- und Lebensmit telhygiene. URL: https://www.infektionsschutz.de/hygienetipps/kuechen-undlebensmittelhygiene.html (Accessed 9 February 2021).

37. Robert Koch Institute: The Robert Koch Institute: Tasks and Aims. URL: www.rki.de/EN/Content/Institute/institute_node.html;jsessionid=FE489004A4A291BC927E49A5670A8969.internet062 (Accessed 11 February 2021).

38. Robert Koch Institute: Infektionsprävention in Heimen. Empfehlung der Kommission für Krankenhaushygiene und Infektionsprävention beim Robert KochInstitut (RKI). Bundesgesundheitsbl. Gesundheitsforsch. Gesundheitsschutz 48 (2005) 1061 - 1080. PMid:16160897; DOI:10.1007/s00103-005-1126-2

39. Robert Koch Institute: Aufbereitung von Medizinprodukten. URL: https:// www.rki.de/DE/Content/Infekt/Krankenhaushygiene/Aufb_MedProd/Aufb_ MedProd_node.html;jsessionid = 7C1ACF060F693B0024ÄB2B6AF46B420C.internet072 (Accessed 8 February 2021).

40. Bavarian State Government: Corona Pandemie: Hygienekonzept Gastronomie. Gemeinsame Bekanntmachung der Bayerischen Staatsministerien für Gesundheit und Pflege und für Wirtschaft, Landesentwicklung und Energie. Konsolidierte Lesefassung (As of 6 October 2020).

41. State Government of Baden-Wuerttemberg: Verordnung des Sozialministeriums und des Wirtschaftsministeriums zur Eindämmung von Übertragungen des Corona-Virus (SARS-CoV-2) in Gaststätten (Corona-Verordnung Gaststätten - CoronaVO Gaststätten) vom 16. Mai 2020.

42. State Government of Rhineland-Palatinate: Hygiene- und Schutzmaßnahmen für Gastronomie und Beherbergungsbetriebe (Stand: 4. LVO zur Änderung de 11. CoBeLVO) (2020)

43. The Federal Government of Germany: Coronavirus in Deutschland: https:// www.bundesregierung.de/breg-de/themen/coronavirus/corona-massnahmen-1734724 (Accessed 11 February 2021).

44. Etol Eberhard Tripp GmbH: etolø. Infoblatt: Was passiert mit dem Coronavirus in der Spülmaschine? Stand - 18.03.2020. URL: https://www.etol.de/wpcontent/uploads/Infoblatt_gewerbliches-Sp\%C3 \%BClen-in-Zeiten-des-Coronavirus V02.pdf (Accessed 15 February 2021).

45. Dr. Weigert: Coronavirus SARS-CoV-2 (Covid-19). URL: https://www.drweigert.com/de/coronavirus-sars-cov-2-covid-19 (Accessed 16 February 2021).

46. Arbeitskreis Gewerbliches Geschirrspülen: Praxishandbuch Gewerbliches Geschirrspülen. Kapitel 11: Hygiene. Frankfurt (2019)

47. Arbeitskreis Gewerbliches Geschirrspülen: Englische Übersetzung der Website des Arbeitskreis Gewerbliches Geschirrspülen veröffentlicht. (16.02.2021) URL: https://www.akggs.de/de/news/Englische-Uebersetzung-der-Website-des-Arbeitskreis-Gewerbliches-Geschirrspuelen-veroeffentlicht (Accessed 22 March 2021).

48. von Esmarch-Rummler, B. (Ed.): Praxishandbuch Gewerbliches Geschirrspülen, Arbeits Gewerblichs Geschirrspülen, Frankfurt ISBN 978-3-84408014-8.

49. Arbeitskreis Gewerbliches Geschirrspülen: Merkblatt Gewerbliches Geschirrspülen in der Corona-Pandemie. AKGGS, Frankfurt, April 2021.

50. Bundesinstitut für Risikobewertung: Hygienische Wirksamkeit von Spülgeräten zum Reinigen von Trinkgläsern in der Gastronomie. Stellungnahme Nr. 027/ 2008 des BfR vom 1. April 2008 URL: https://www.bfr.bund.de/cm/343/hygienische wirksamkeit von spuelgeraeten zum reinigen von_trinkglaesern in_der_gastronomie.pdf (Accessed 24 April 2021).

51. Bundesinstitut für Risikobewertung: Kann das neuartige Coronavirus über Lebensmittel und Gegenstände übertragen werden? Aktualisierte Fragen und Antworten des BfR vom 9. April 2021 URL: https://www.bfr.bund.de/cm/343/ kann-das-neuartige-coronavirus-ueber-lebensmittel-und-gegenstaende-uebertragen-werden.pdf (Accessed 23 April 2021).

52. International Electrotechnical Commission: IEC 63136:2019. Electric Dishwashers for Commercial Use - Test Methods for Measuring the Performance, IEC, Geneva, Switzerland (2019)

Received: 06.05.2021

Accepted: 01.06.2021 
Bibliography

DOI 10.1515/tsd-2020-2373

Tenside Surf. Det. 58 (2021) 5, page 320-333

(c) 2021 Walter de Gruyter GmbH, Berlin/Boston, Germany

ISSN 0932-3414 · e-ISSN 2195-8564

\section{Correspondence address}

Dr. Sarah Schulze Struchtrup

Institute of Agricultural Engineering/Household Technology

University of Bonn

Nussallee 5

53115 Bonn

Germany

Tel.: + 49-228-73-305

Fax: +49-228-73-2596

E-mail: haushaltstechnik@uni-bonn.de stamminger@uni-bonn.de

\section{The authors of this paper}

Dr. Sarah Schulze Struchtrup, Food Technologist, completed her doctorate at the University of Bonn in the Department of Household and Appliance Technology in 2021. She was active as secretary in national and international working groups focussing on hygiene in the household dishwasher.

Prof. Dr. Rainer Stamminger, Engineer, works as a senior professor for Household and Appliance Technology at the University of Bonn.

Dr. Britta von Esmarch-Rummler holds a degree in Ecotrophology and completed her doctorate in 2009 at the University of Bonn in the Department of Household Technology. In her doctoral thesis, she worked on a physical method for measuring drying performance in dishwashers, which received an award. She is active in various national and international committees and working groups in the field of "commercial dishwashing", where she also holds the chair in some of them. 